\section{Korolov 0., Pavlishin P., Titlov 0., Mironchuk V.}

\title{
EXPERIMENTAL STUDY OF THE TRANSITION OF TWO TYPES OF WEDGE GATE VALVES
}

Об’єктом дослідження є вид енергетичної арматури - засувка або клинова арматура. Засувки або клинова арматура займає провідне місце серед енергетичної арматури. Вона має мінімальний гідравлічний опір, практично лінійну залежність витрати від ступеня відкриття та має широке застосування на трубопровідних системах широкого призначення. Одним із проблемних місць такої арматури є втрата герметичності або пропуск клинових засувок. Крім цього, більш складна конструкиія підвищує ймовірність відмови такої арматури. Для вирішення цієї проблеми пропонується виконати експериментальне дослідження пропуску засувок в залежності від зусилля їх закриття, а також дослідження тренда цієї залежності.

Дослідження проводилися на стенді, що забезпечує тиск повітря до 3,0-3,5 МПа та укомплектований чавунною та латунною засувками. Пропуск повітря вимірювали об'ємним способом, витісняючи воду з вимірювальної комірки. Для створення зусилля на штоку, що замикає арматуру, використовувався динамометрический ключ КД-230 (Росія), що дозволяє вимірювати крутний момент до $230 \mathrm{H} \cdot$ м. Методика експерименту полягала в наступному. Динамометричним ключем необхідним зусиллям закривали арматуру, потім включали компресор і досягали необхідного тиску. Пропуск повітря вимірювали заповненням вимірювальної комірки за час, що фіксується секундоміром.

Обробка отриманих експериментальних даних дозволила отримати наступні залежності відносного пропуску арматури від величини крутного моменту для чавунної засувки: $(Q / \sqrt{\Delta P})=3458 \cdot M^{(-1,069)}$ та для латунної засувки: $(Q / \sqrt{\Delta P})=6893 \cdot M^{(-2,435)}$. Показано, що засувки так само як і раніше досліджені клапани та вентилі мають один тренд: $(Q / \sqrt{\Delta P})=C \cdot M^{(-g)}$. Показник ступеня крутного моменту показує, чим він більший за абсолютним значенням, тим запірні характеристики арматури - кращі. Так, для забезпечення однакового пропуску повітря, крутний момент на чавунній арматурі повинен мати більші значення, ніж для досліджуваної латунної засувки.

Ключові слова: клинова арматура, крутний момент, відносний пропуск повітря, герметичність арматури, чавунна засувка, латунна засувка.

\section{Introduction}

The reliability of pipeline valves in general determines the reliability of any equipment. Timely detection of valve damage will help to avoid unplanned stops and accidents of the heat-power equipment of the station [1-3]. Conversely, failure of critical valves can lead to serious events. One can recall the failure of the pulse valve of the pressure compensator at the Three Mile Island NPP (nuclear power plant) [4], which ended in the first serious accident at world nuclear power plants. A similar failure of the PC PRV (pulse pressure relief valve of the pressure compensation system) was noted at the Rivne NPP, Ukraine, but it was detected and eliminated in time. Failure of valves in refrigeration equipment also leads to serious consequences [5]. Thus, the object of this study is the type of power valves - gate valve or wedge valve.

Gate valves or wedge valve take a leading place among power valves. Firstly, when the rod is fully raised, it has the minimum hydraulic resistance, among other types of valves [6, 7]. Secondly, the almost linear dependence of the flow rate on the level of the rod lift provides it with a place in automatic control systems or supporting costs, for example, in drainage systems of heaters, on heating mains of heating systems [3]. In addition, such valve has two seating surfaces in series, which increases the reliability of its closure. However, this design is more complex compared, for example, with the design of the valve, which increases the likelihood of failure of such valves $[3,6]$.

The relevance of the work is due to the practical absence of such studies of valve. Analysis of publications on this topic showed the presence of a limited number of works devoted to it [8-10]. Therefore, it seems relevant to expand the study of the tightness of valves with various closing efforts on wedge gate valves. So, the aim of this research is to study the tightness of wedge gate valves with different closing forces by constructing the dependence of the relative valve tolerance on the closing force and analyzing this dependence.

\section{Methods of research}

Experimental studies were carried out on a bench that provides air pressure with an AK-50 compressor (USSR) up to 3.0-3.5 MPa (Fig. 1). 


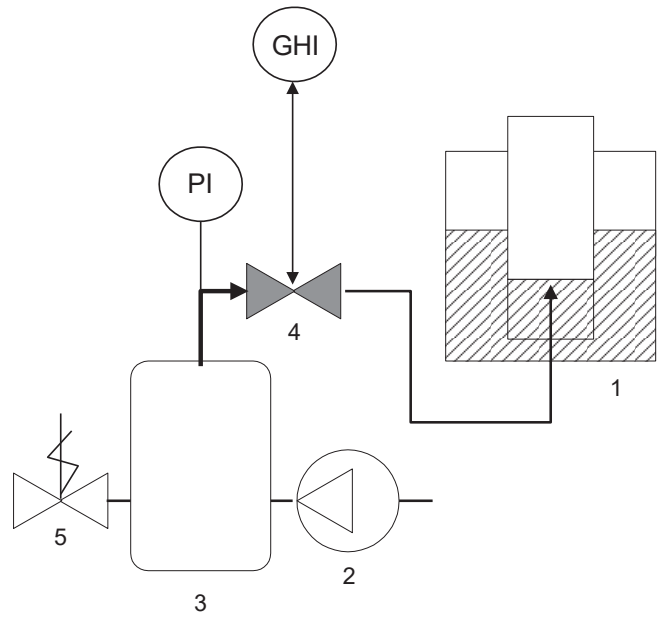

Fig. 1. Scheme of the experimental stand: 1 - measuring cell; 2 - AK-50 compressar A; 3 - receiver 4 - studied valve; 5 - safety valve; PI - pressure gauge; GHI - torque wrench

For a smooth air supply to the latch 4, the compressor 2 worked on the receiver 3 , with a volume of about 5 liters. Air flow was measured in a volumetric way, displacing water from measuring cell 1 . To create a force on the rod that closes the valve 4, let's use a KD-230 torque wrench (Russia), which allows measuring torque up to $230 \mathrm{~N} \cdot \mathrm{m}$.

The experimental technique was as follows. The valve 4 was closed with a torque wrench with the required force, then the compressor 3 was turned on and the required pressure was reached. Air transition was measured by filling the measuring cell over a period of time, which was recorded by a stopwatch. The experimental results are presented in Tables 1, 2.

Table 1

Air transition by the cast iron gate valve

\begin{tabular}{|c|c|c|c|c|c|}
\hline$V_{\text {air, }} \mathrm{ml}$ & $t, \mathrm{~s}$ & $\square, \mathrm{ml} / \mathrm{min}$ & $\Delta P$, atm & $M, \mathrm{~N} \cdot \mathrm{m}$ & $(\square / P)^{0.5}$ \\
\hline 1 & 2 & 3 & 4 & 5 & 6 \\
\hline 150 & 27.12 & 331.8584 & 2.4 & 9.2 & 214.2137 \\
\hline 150 & 12.07 & 745.6504 & 3.2 & 9.2 & 416.8312 \\
\hline 150 & 8.63 & 1042.874 & 4 & 9.2 & 521.4368 \\
\hline 150 & 6.99 & 1287.554 & 5.2 & 9.2 & 564.6296 \\
\hline 150 & 6.48 & 1388.889 & 6.4 & 9.2 & 549.0065 \\
\hline 150 & 6.06 & 1485.149 & 7.2 & 9.2 & 553.4822 \\
\hline 150 & 5.59 & 1610.018 & 8 & 9.2 & 569.2273 \\
\hline 150 & 4.98 & 1807.229 & 8.8 & 9.2 & 609.2167 \\
\hline 150 & 4.85 & 1855.67 & 9.6 & 9.2 & 598.915 \\
\hline 150 & 4.6 & 1956.522 & 10.4 & 9.2 & 606.6916 \\
\hline 150 & 4.52 & 1991.15 & 11.2 & 9.2 & 594.97 \\
\hline 150 & 4.41 & 2040.816 & 12 & 9.2 & 589.1329 \\
\hline 280 & 15.46 & 1086.675 & 2.4 & 4 & 701.4459 \\
\hline 280 & 12.15 & 1382.716 & 3.2 & 4 & 772.9618 \\
\hline 280 & 10.26 & 1637.427 & 4 & 4 & 818.7135 \\
\hline 280 & 8.01 & 2097.378 & 5.2 & 4 & 919.7612 \\
\hline 280 & 7.63 & 2201.835 & 6.4 & 4 & 870.3516 \\
\hline 280 & 7.08 & 2372.881 & 7.2 & 4 & 884.3207 \\
\hline 280 & 6.56 & 2560.976 & 8 & 4 & 905.4416 \\
\hline 280 & 5.89 & 2852.292 & 8.8 & 4 & 961.5074 \\
\hline
\end{tabular}

Continuation of Table 1

\begin{tabular}{|c|c|c|c|c|c|}
\hline 1 & 2 & 3 & 4 & 5 & 6 \\
\hline 280 & 5.48 & 3065.693 & 9.6 & 4 & 989.4483 \\
\hline 280 & 5.05 & 3326.733 & 10.4 & 4 & 1031.576 \\
\hline 280 & 4.81 & 3492.723 & 11.2 & 4 & 1043.651 \\
\hline 280 & 4.65 & 3612.903 & 12 & 4 & 1042.955 \\
\hline 280 & 18.26 & 920.0438 & 2.4 & 5.2 & 593.8857 \\
\hline 280 & 13.1 & 1282.443 & 3.2 & 5.2 & 716.9073 \\
\hline 280 & 11.28 & 1489.362 & 4 & 5.2 & 744.6809 \\
\hline 280 & 9.36 & 1794.872 & 5.2 & 5.2 & 787.1034 \\
\hline 280 & 7.75 & 2167.742 & 6.4 & 5.2 & 856.8752 \\
\hline 280 & 7.45 & 2255.034 & 7.2 & 5.2 & 840.4014 \\
\hline 280 & 6.83 & 2459.736 & 8 & 5.2 & 869.6482 \\
\hline 280 & 6.55 & 2564.885 & 8.8 & 5.2 & 864.6227 \\
\hline 280 & 6.38 & 2633.229 & 9.6 & 5.2 & 849.871 \\
\hline 280 & 6.2 & 2709.677 & 10.4 & 5.2 & 840.2353 \\
\hline 280 & 5.95 & 2823.529 & 11.2 & 5.2 & 843.6908 \\
\hline 280 & 5.66 & 2968.198 & 12 & 5.2 & 856.8449 \\
\hline 280 & 20.2 & 831.6832 & 2.4 & 5.7 & 536.8492 \\
\hline 280 & 14.62 & 1149.111 & 3.2 & 5.7 & 642.3725 \\
\hline 280 & 11.63 & 1444.54 & 4 & 5.7 & 722.27 \\
\hline 280 & 9.68 & 1735.537 & 5.2 & 5.7 & 761.0834 \\
\hline 280 & 8.79 & 1911.263 & 6.4 & 5.7 & 755.493 \\
\hline 280 & 7.86 & 2137.405 & 7.2 & 5.7 & 796.5637 \\
\hline 280 & 6.73 & 2496.285 & 8 & 5.7 & 882.5701 \\
\hline 280 & 6.43 & 2612.753 & 8.8 & 5.7 & 880.7588 \\
\hline 280 & 5.79 & 2901.554 & 9.6 & 5.7 & 936.4727 \\
\hline 280 & 5.95 & 2823.529 & 10.4 & 5.7 & 875.5393 \\
\hline 280 & 5.56 & 3021.583 & 11.2 & 5.7 & 902.8705 \\
\hline 280 & 6.1 & 2754.098 & 12 & 5.7 & 795.0397 \\
\hline 280 & 29.06 & 578.1142 & 2.4 & 6.9 & 373.1711 \\
\hline 280 & 22.72 & 739.4366 & 3.2 & 6.9 & 413.3576 \\
\hline 280 & 17.15 & 979.5918 & 4 & 6.9 & 489.7959 \\
\hline 280 & 13.43 & 1250.931 & 5.2 & 6.9 & 548.5694 \\
\hline 280 & 10.58 & 1587.902 & 6.4 & 6.9 & 627.6733 \\
\hline 280 & 9.93 & 1691.843 & 7.2 & 6.9 & 630.5126 \\
\hline 280 & 9.08 & 1850.22 & 8 & 6.9 & 654.1516 \\
\hline 280 & 8.5 & 1976.471 & 8.8 & 6.9 & 666.2681 \\
\hline 280 & 7.6 & 2210.526 & 9.6 & 6.9 & 713.4443 \\
\hline 280 & 7.29 & 2304.527 & 10.4 & 6.9 & 714.6034 \\
\hline 280 & 7.02 & 2393.162 & 11.2 & 6.9 & 715.094 \\
\hline 280 & 6.82 & 2463.343 & 12 & 6.9 & 711.1059 \\
\hline 150 & 18.33 & 490.9984 & 2.4 & 8 & 316.9381 \\
\hline 150 & 11.12 & 809.3525 & 3.2 & 8 & 452.4418 \\
\hline 150 & 9.05 & 994.4751 & 4 & 8 & 497.2376 \\
\hline 150 & 7.32 & 1229.508 & 5.2 & 8 & 539.175 \\
\hline 150 & 6.27 & 1435.407 & 6.4 & 8 & 567.3943 \\
\hline 150 & 5.97 & 1507.538 & 7.2 & 8 & 561.8261 \\
\hline 150 & 5.4 & 1666.667 & 8 & 8 & 589.2557 \\
\hline 150 & 4.83 & 1863.354 & 8.8 & 8 & 628.1365 \\
\hline 150 & 4.67 & 1927.195 & 9.6 & 8 & 621.9995 \\
\hline 150 & 4.51 & 1995.565 & 10.4 & 8 & 618.7986 \\
\hline 150 & 4.43 & 2031.603 & 11.2 & 8 & 607.0574 \\
\hline 150 & 4.25 & 2117.647 & 12 & 8 & 611.312 \\
\hline
\end{tabular}

Note: $V_{\text {air }}$ - air volume; $t$ - transit time of the air volume; $M$ torque; $\square-$ air consumption (transition); $\Delta P$ - pressure drop across the gate valve; $(\Phi / P)^{0.5}-$ complex 
Air transition be the brass gate valve

Table 2

\begin{tabular}{|c|c|c|c|c|c|}
\hline$V_{\text {air },} \mathrm{ml}$ & $\overline{t, \mathrm{~s}}$ & $\square, \mathrm{ml} / \mathrm{min}$ & $\Delta P$, atm & $M, \mathrm{~N} \cdot \mathrm{m}$ & $(\square / P)^{0.5}$ \\
\hline 290 & 15.46 & 1125.485 & 2.4 & 4 & 726.4975 \\
\hline 290 & 12.15 & 1432.099 & 3.2 & 4 & 800.5675 \\
\hline 290 & 10.26 & 1695.906 & 4 & 4 & 847.9532 \\
\hline 290 & 8.01 & 2172.285 & 5.2 & 4 & 952.6098 \\
\hline 290 & 7.63 & 2280.472 & 6.4 & 4 & 901.4356 \\
\hline 290 & 7.08 & 2457.627 & 7.2 & 4 & 915.9036 \\
\hline 290 & 6.56 & 2652.439 & 8 & 4 & 937.7788 \\
\hline 290 & 5.89 & 2954.16 & 8.8 & 4 & 995.847 \\
\hline 290 & 5.48 & 3175.182 & 9.6 & 4 & 1024.786 \\
\hline 290 & 5.05 & 3445.545 & 10.4 & 4 & 1068.418 \\
\hline 290 & 4.81 & 3617.464 & 11.2 & 4 & 1080.924 \\
\hline 290 & 4.65 & 3741.935 & 12 & 4 & 1080.204 \\
\hline 290 & 18.26 & 952.9025 & 2.4 & 5.2 & 615.0959 \\
\hline 290 & 13.1 & 1328.244 & 3.2 & 5.2 & 742.5111 \\
\hline 290 & 11.28 & 1542.553 & 4 & 5.2 & 771.2766 \\
\hline 290 & 9.36 & 1858.974 & 5.2 & 5.2 & 815.2142 \\
\hline 290 & 7.45 & 2335.57 & 7.2 & 5.2 & 870.4157 \\
\hline 290 & 20.2 & 861.3861 & 2.4 & 5.7 & 556.0224 \\
\hline 290 & 14.62 & 1190.15 & 3.2 & 5.7 & 665.3143 \\
\hline 290 & 11.63 & 1496.131 & 4 & 5.7 & 748.0653 \\
\hline 290 & 9.68 & 1797.521 & 5.2 & 5.7 & 788.265 \\
\hline 290 & 8.79 & 1979.522 & 6.4 & 5.7 & 782.4748 \\
\hline 290 & 7.86 & 2213.74 & 7.2 & 5.7 & 825.0124 \\
\hline 290 & 6.1 & 2852.459 & 12 & 5.7 & 823.434 \\
\hline 290 & 29.06 & 598.7612 & 2.4 & 6.9 & 386.4987 \\
\hline 290 & 22.72 & 765.8451 & 3.2 & 6.9 & 428.1204 \\
\hline 290 & 17.15 & 1014.577 & 4 & 6.9 & 507.2886 \\
\hline 290 & 13.43 & 1295.607 & 5.2 & 6.9 & 568.1612 \\
\hline 290 & 10.58 & 1644.612 & 6.4 & 6.9 & 650.0902 \\
\hline 290 & 9.93 & 1752.266 & 7.2 & 6.9 & 653.0309 \\
\hline 290 & 9.08 & 1916.3 & 8 & 6.9 & 677.5142 \\
\hline 290 & 8.5 & 2047.059 & 8.8 & 6.9 & 690.0634 \\
\hline 150 & 18.33 & 490.9984 & 2.4 & 8 & 316.9381 \\
\hline 150 & 11.12 & 809.3525 & 3.2 & 8 & 452.4418 \\
\hline 150 & 9.05 & 994.4751 & 4 & 8 & 497.2376 \\
\hline 150 & 7.32 & 1229.508 & 5.2 & 8 & 539.175 \\
\hline 150 & 5.97 & 1507.538 & 7.2 & 8 & 561.8261 \\
\hline 290 & 17.81 & 976.9792 & 12 & 17 & 282.0296 \\
\hline 290 & 32.43 & 536.5402 & 12 & 28 & 154.8858 \\
\hline 20 & 15.76 & 76.14213 & 12 & 33 & 21.98034 \\
\hline 20 & 37.59 & 31.92338 & 11.2 & 36 & 9.538935 \\
\hline 250 & 2.1 & 7142.857 & 14 & 1 & 1909.009 \\
\hline 250 & 2.2 & 6818.182 & 10.4 & 1 & 2114.228 \\
\hline 250 & 2.87 & 5226.481 & 8 & 1 & 1847.84 \\
\hline 250 & 3.05 & 4918.033 & 6 & 1 & 2007.778 \\
\hline 250 & 3.14 & 4777.07 & 4.4 & 1 & 2277.379 \\
\hline
\end{tabular}

Note: $V_{\text {air }}$ - air volume; $t$ - transit time of the air volume; $M-$ torque; $\square$ - air consumption (transition); $\Delta P$ - pressure drop across the gate valve; $(\emptyset / P)^{0.5}-$ complex

The tabular presentation of the results is important for checking the data, but does not give an idea of the nature of the valve transition. For this, it is advisable to process the experimental data according to previously obtained criteria [8].

\section{Research results and discussion}

Processing the obtained experimental data allows to obtain the following dependences (Fig. 2, 3).

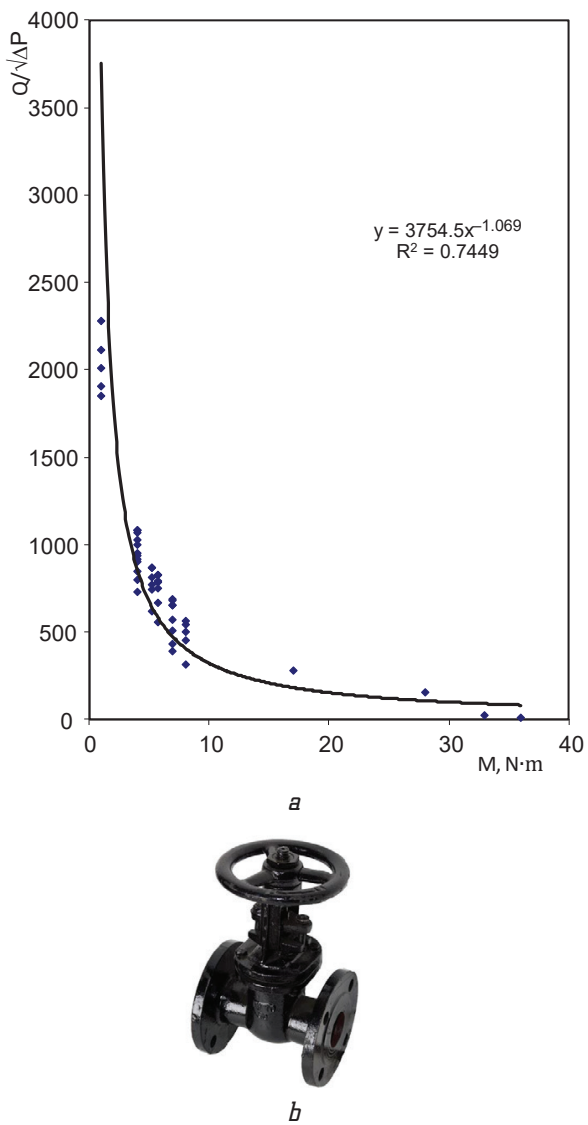

Fig. 2. Cast iron gate valve: $a$ - dependence of the relative gap of the valve on the magnitude of the torque; $b$ - appearance

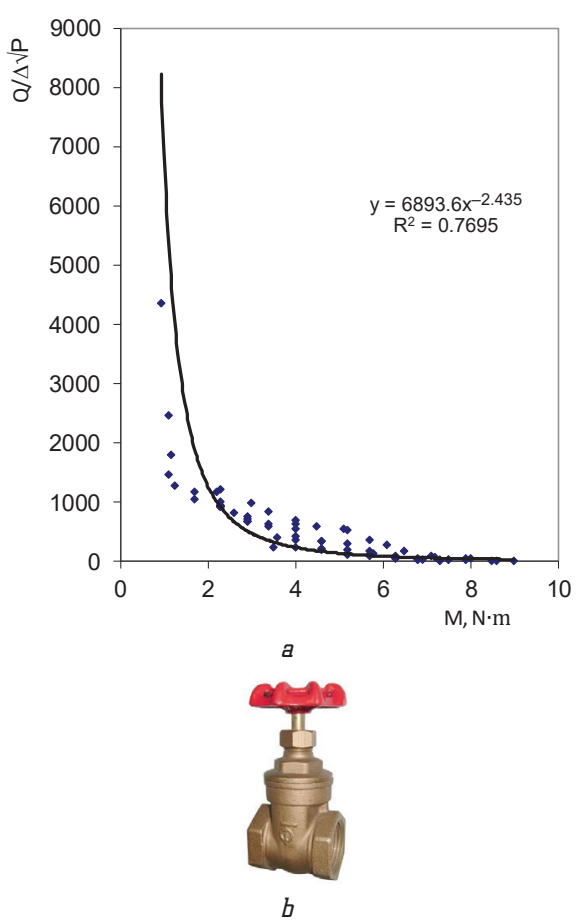

Fig. 3. Brass gate valve: $a$ - dependence of the relative gap of the valve on the magnitude of the torque; $b$ - appearance 
The experiment showed that the gate valves, just as previously studied valves [8] and valves have one trend, namely, obey the equation:

$$
(Q / \sqrt{\Delta P})=C \cdot M^{(-g)},
$$

where $Q$ - air consumption (transition), $\mathrm{ml} / \mathrm{s} ; \Delta P$ - pressure drop across the gate valve, $\mathrm{MPa}$; $C$ - coefficient; $M$ torque, N.m; $g$ - exponent with $M$.

It is also possible to see that the indicator of the degree of torque is 1.069 for cast iron valve, and 2.435 for brass valve. This means that in order to ensure the same transmission of air, the torque on cast iron valve must have larger values than for the brass.

A visual examination of these gate valves shows that cast iron valve is in operation, while brass valve is brand new. That is, an indicator of the degree of torque allows to evaluate the quality of the seating surfaces of the gate valves.

The dimensional coefficient $\mathrm{C}$ also indicates the quality of the seating surfaces, directly relating the valve transition to its value, however, a solid indicator has a significantly greater effect.

\section{Conclusions}

An experimental study confirms that the gate valves also obey the previously established criteria dependencies [8]. The influence of the coefficients and exponents in the obtained dependence on the quality of the seating surfaces and the valve tolerance is shown. This study leads to the need to expand the incoming control of valves on such stands.

\section{References}

1. Gurevich, D. F., Shiriaev, V. V., Paikin, I. Kh. (1982). Armatura atomnykh elektrostancii. Moscow: Energoizdat, 312.
2. Imbrickii, M. I. (1981). Spravochnik po armature teplovykh elektrostancii. Moscow: Energoizdat, 304.

3. Gurevich, D. F. (2008). Raschet i konstruirovanie truboprovodnoi armatury: Raschet truboprovodnoi armatury. Moscow: LKI, 480

4. Hewitt, G. F., Collier, J. G. (2000). Introduction to Nuclear Power. CRC Press, 320. doi: http://doi.org/10.1201/b15077

5. Korolev, A. V., Chervonenko, P. P. (2011). Neustoichivost raboty skhem podderzhaniia urovnia $\mathrm{v}$ sistemakh szhizhennogo gaza. Kholodilna tekhnika i tekhnologiia, 11, 25-29.

6. Gurevich, D. F., Zarinskii, O. N., Kosykh, S. I.; Kosykh, S. I. (Ed.) (1982). Truboprovodnaia armatura s avtomaticheskim upravleniem. Leningrad: Mashinostroenie, 320.

7. Makarov, A. N., Sherman, M. Ia. (1998). Raschet drosselnykh ustroistv. Moscow: Atomizdat, 283

8. Koroliov, A. V., Pavlyshyn, P. Y., Bandurko, I. V. (2018). Experimental Research of Valve Tightness at Different Closure Forces. Nuclear and Radiation Safety, 4 (80), 14-17. doi: http:// doi.org/10.32918/nrs.2018.4(80).03

9. Chernoshtan, V. I., Kuznecov, V. A. (2001). Truboprovodnaia armatura TES. Moscow: Izdatelstvo MEI, 368.

10. Goshko, A. I. (2003). Armatura truboprovodnaia celevogo naznacheniia. Kn.1: Vybor. Ekspluataciia. Remont. Moscow: Mashinostroenie, 432

Korolov Oleksander, Doctor of Technical Sciences, Professor, Department of Nuclear Power Plants, Odessa National Polytechnic University, Ukraine, ORCID: http://orcid.org/0000-0002-4158-7966, e-mail:korol118@ukr.net

Pavlyshin Pavel, Acting President, National Nuclear Energy Generating Company «Energoatom», Kyiv, Ukraine, ORCID: http:// orcid.org/0000-0002-3417-4346

Titlov Alexander, Doctor of Technical Sciences, Professor, Head of Department of Heat-and-Power Engineering and Oil-and-Gas Transportation and Storing, Odessa National Academy of Food Technologies, Ukraine, ORCID: http://orcid.org/0000-0003-1908-5713, e-mail: titlov1959@gmail.com

Mironchuk Valentin, Department of Nuclear Power Plants, Odessa National Polytechnic University, Ukraine, ORCID: https://orcid.org/ 0000-0002-4630-5331, e-mail: mironchikvalik@gmail.com 